\title{
Identification of Antibiotic Resistant Gram-Negative Bacteria in a Popular Street-Food Item (Chatpati) in Dhaka University Campus, Bangladesh
}

\author{
Moumita Dey ${ }^{1, ~ *, ~ M a n s u r a ~ M o k b u l ~}{ }^{1}$, Ila Ismail ${ }^{2}$, Sharmin Rumi Alim² \\ ${ }^{1}$ Department of Food Technology and Nutrition Science, Noakhali Science and Technology University, Noakhali, Bangladesh \\ ${ }^{2}$ Institute of Nutrition and Food Science, University of Dhaka, Dhaka, Bangladesh
}

\section{Email address:}

moumitadeydu@gmail.com (M. Dey), mansura@nstu.edu.bd (M. Mokbul), ila_ismail08@yahoo.com (I. Ismail),

rumialim@yahoo.com (S. R. Alim)

${ }^{*}$ Corresponding author

\section{To cite this article:}

Moumita Dey, Mansura Mokbul, Ila Ismail, Sharmin Rumi Alim. Identification of Antibiotic Resistant Gram-Negative Bacteria in a Popular Street-Food Item (Chatpati) in Dhaka University Campus, Bangladesh. Frontiers in Environmental Microbiology.

Vol. 4, No. 2, 2018, pp. 75-80. doi: 10.11648/j.fem.20180402.15

Received: March 7, 2018; Accepted: March 29, 2018; Published: May 7, 2018

\begin{abstract}
Presence of antibiotic resistant bacteria in street-foods has become a global health concern. In this study, we have thoroughly investigated the bacteriological quality of Chatpati (CHT) samples collected from 7 different locations of Dhaka University campus. Various selective and differential media, Gram staining and biochemical tests were carried out for isolation, enumeration and characterization of the isolates. The total bacterial count varied in samples from 7 locations ranging from $1.1 \times 10^{3}$ to $4.1 \times 106 \mathrm{CFU} / \mathrm{g}$. Klebsiella spp., Escherichia coli (E. coli), Enterobacter spp., Vibrio spp., Proteus spp., Pseudomonas aeruginosa and Aeromonas spp. were identified in the collected CHT samples. Isolates were then subjected to antibiotic susceptibility test. For antibiogram profiling, Ampicillin, Colistin, Chloramphenicol, Ceftriaxone, Ciprofloxacin and Nitrofurantoin were employed in this study. Multiple antibiotic resistance index (MRI\%) of the isolates were found to be ranged from 16.67 to $66.67 \%$. Majority of the isolates showed resistance against Ampicillin and Nitrofurantoin. Therefore, it may be concluded that the consumption of CHT from this area may be severely detrimental to health due to the presence of antibiotic resistant bacteria.
\end{abstract}

Keywords: Antibiotic Resistant, Street-Food, Chatpati, Bacterial Count, Antibiogram

\section{Introduction}

Food plays a predominant role in sustaining human health. However, inadvertent contamination usually associate during the preparation of foods [1]. A wide variety of foods such as vegetables, poultry, confectionary meat and meat products are usually prepared by food vendors in many developing countries. Food and agricultural organization define streetfood as "Ready to eat foods and beverages prepared and sold by vendors especially in streets and other public places for immediate consumption." Street-foods includes fast foods, snacks, sliced fruits, salads, junk foods, meals, beverages and drinks [2]. Street-foods are appreciated for their unique flavors and convenience. An important socioeconomic role is played by the street-foods as they meet the food and nutritional requirements of the city consumers at affordable prices [3, 4]. In many developing countries, street-foods assure livelihood for a greater number of populations and food security for low income urban population [5]. There is a rapid increase of urban population in Bangladesh and in Dhaka city the population almost doubled from 5.3 to 9.3 million in the last decade. Therefore the demand for relatively inexpensive ready-to-eat foods is increasing day by day particularly for the people spending most of the time outside the house and having little time and money to spend on food. Consumers belonging to this categories are students, itinerant unskilled laborers and the homeless [6]. However, street-food vendors are often poor and uneducated [7]. The lack of knowledge in safe food handling, traditional processing methods, ambient holding temperature, and poor 
personal hygiene of food handlers are some of the major causes of contamination of street-foods [8, 9]. Microbial contamination of street-food leads to the foodborne illnesses considered as the major public health problem [10, 11]. In humans, foodborne diseases result from more than 250 different types of bacteria, viruses, parasites, metals, toxins and prions [12]. Bacterial agents cause foodborne infections which may lead to hospitalizations and death. In Bangladesh, about 30 million people are suffering from foodborne illnesses each year where diarrhoeal diseases are the most common [13].

Apart from microbial load, the multi-drug resistance of foodborne microorganisms aggravates the food safety situation. Selective pressure towards resistant bacteria has been created by the possibility of horizontal transfer of resistance determinants and due to the over-use and misuse of antibiotics. As a result of these factors, the severity of the problem is significantly increased [14]. The intimidating probability is that most pathogenic bacteria threatening human health will soon be resistant to all known antibiotics [15]. According to the WHO's report on global surveillance on antimicrobial resistance, the ability to treat common infections in the community and hospitals is put at risk due to the antibiotic resistance throughout the world which is not a prediction for the future but is happening right now [16]. Resistance to a given antibiotic may be an inherent characteristic of the organism or it may be acquired. Mutations in the bacterial genome or acquisition of additional genes coding for a resistance mechanism leads to the acquired resistance against an antimicrobial agent. The defensive mechanism of the bacteria is altered due to these genetic changes because these genetic changes lead to the change in membrane permeability, active transport of antibiotics, enzymatic inactivation of antibiotics, target modification, routing metabolic pathways around the disrupted point etc. $[17,18]$.

Various types of street-foods are sold by vendors in Bangladesh and among these foods, CHT is very popular among university students. Since, street-foods are generally high in bacterial count and spreading of antibiotic resistance through food chain is a global concern, we conducted this study to identify antibiotic resistant Gram-negative bacteria in CHT samples collected from seven different locations of Dhaka University campus.

\section{Materials and Methods}

\subsection{Sample Collection}

CHT samples were aseptically collected during July to August, 2015. A total of 21 samples were collected for the study purpose having 3 samples from each site. Samples were collected in sterile containers and analyzed within one (1) hour of procurement.

\subsection{Sample Processing}

Ten (10) grams sample was mixed with previously prepared $90 \mathrm{ml}$ peptone water in a flask. The flask was plugged with cotton and shaked for homogenization of the samples. After proper mixing of the sample, $1 \mathrm{ml}$ of the sample solution was pipetted and transferred into sterilized cotton plugged test tubes containing $9 \mathrm{ml}$ of $0.1 \%$ peptone water. Then they were mixed thoroughly by shaking. Thus the initial dilution of homogenate was prepared and from this homogenization further serial dilutions were made.

\subsection{Bacteriological Studies}

For the isolation of bacteria, the pour and streak plate methods were followed in this study. Plate count agar (PCA), MacConkey (MC) agar, Salmonella-Shigella (SS) agar, Thiosulphate Citrate Bile Sucrose (TCBS) agar and Eiosin Methylene Blue (EMB) agar media were used for the isolation purpose. SS agar was used for the better colony characteristics of Salmonella spp. and better growth of Shigella spp. EMB is the selective and differential media for coliforms. Green metallic sheen on EMB plate indicates the presence of $E$. coli. TCBS agar is a selective media which is used for isolating Vibrio spp. [19]. For antibiotic resistance study, Muller-Hinton agar and Muller-Hinton broth were used. All the media were prepared according to the instruction given by the manufacturer. The samples were diluted 10 folds upto $10^{-6}$ according to American Public Health Association (APHA) sample dilution guidelines [20]. Pour plate method was used for isolation of bacteria from CHT samples and plates were incubated at $37^{\circ} \mathrm{C}$ in an incubator for 24 hours [21]. Different types of bacterial colony grown on PCA, MC, EMB and TCBS agar were collected and maintained in nutrient agar slant. For further analysis, bacterial colonies grown on agar plates were tested immediately after their growth for morphological and cultural characteristics. The $\mathrm{pH}$ of the samples was determined with the help of $\mathrm{pH}$ paper strip, directly at the collection points.

\subsection{Identification of Isolates}

Some biochemical tests such as Kliger's Iron Agar (KIA) test, Motility Indole Urease (MIU) test, Catalase and Oxidase tests were performed for the identification of bacterial isolates.

\subsection{Antibiogram Profiling}

Antibiotic sensitivity test was carried out for the representative isolates of all identified genus against 6 antibiotics- ampicillin (10 $\mu \mathrm{g})$, ciprofloxacin $(5 \mu \mathrm{g})$, ceftriaxone $(30 \mu \mathrm{g})$, colistin $(10 \mu \mathrm{g})$, nitrofurantoin $(300 \mu \mathrm{g})$ and chloramphenicol $(30 \mu \mathrm{g})$ by disc diffusion method [22] and multiple antibiotic resistant index (MRI\%) was determined [23], using the formula:

$\mathrm{MRI} \%=\frac{\text { No. of antibiotics to which pathogens showed resistance }}{\text { No. of antibiotics used }}$

\section{Results and Discussion}

We have found significant bacterial load in the collected CHT 
samples. The total aerobic bacterial load ranged between $1.1 \times$ $10^{3}-4.1 \times 10^{6} \mathrm{CFU} / \mathrm{g}$. The $\mathrm{pH}$ of the samples ranged between 4.5 -5.5. The acidic condition in the CHT samples could be attributed to the use of tamarind juice. The bacterial load of samples on different agar media is presented in Table 1.

Table 1. Bacterial load on different media.

\begin{tabular}{llllll}
\hline Sample No. & PCA & MC & SS & TCBS & EMB \\
\hline 1 & $3.1 \times 10^{3}$ & $2.0 \times 10^{3}$ & Nil & Nil & $2.6 \times 10^{3}$ \\
2 & $1.1 \times 10^{3}$ & $9.0 \times 10^{2}$ & Nil & Nil & $6.0 \times 10^{2}$ \\
3 & $2.0 \times 10^{3}$ & $1.2 \times 10^{3}$ & Nil & Nil & $1.7 \times 10^{3}$ \\
4 & $9.0 \times 10^{5}$ & $5.0 \times 10^{5}$ & Nil & Nil & $7.1 \times 10^{5}$ \\
5 & $4.1 \times 10^{6}$ & $5.7 \times 10^{5}$ & Nil & Nil & $6.3 \times 10^{5}$ \\
6 & $5.8 \times 10^{4}$ & $1.1 \times 10^{4}$ & Nil & $5.1 \times 10^{2}$ & $1.2 \times 10^{2}$ \\
7 & $2.8 \times 10^{5}$ & $5.0 \times 10^{4}$ & Nil & Nil & $3.9 \times 10^{4}$ \\
\hline
\end{tabular}

The total bacterial load was compared with microbiological guideline for ready-to-eat food [24]. All of the samples were found to have bacterial load above the satisfactory level. Several factors can be attributed to the presence of these microbes in CHT samples, such as improper handling and processing, use of dirty processing utensils like knife and trays, use of contaminated water during washing and dilution, cross contamination from rotten ingredients used for the preparation of CHT etc. [25].

Bacteria were identified by cultural and morphological characteristics and biochemical tests. In this study, E. coli, Pseudomonas aeruginosa, Proteus mirabilis, Klebsiella spp., Aeromonas spp., Enterobacter spp. and Vibrio spp. were found in CHT (Table 2). The presence of E. coli indicates faecal contamination. The bacterial aerosols generated due to sneezing and coughing in public places might be a potential source of the presence of respiratory pathogen Klebsiella spp. in CHT. Detection of Vibrio spp. and Aeromonas spp. indicates water borne contamination of the samples. Handling of soiled notes and currencies by the street-food vendors might be a source of transmission of Pseudomonas spp. The possible source of Proteus spp. is faecal contamination whereas Enterobacter spp. can easily contaminate food since it is widely distributed in the environment [26, 27].

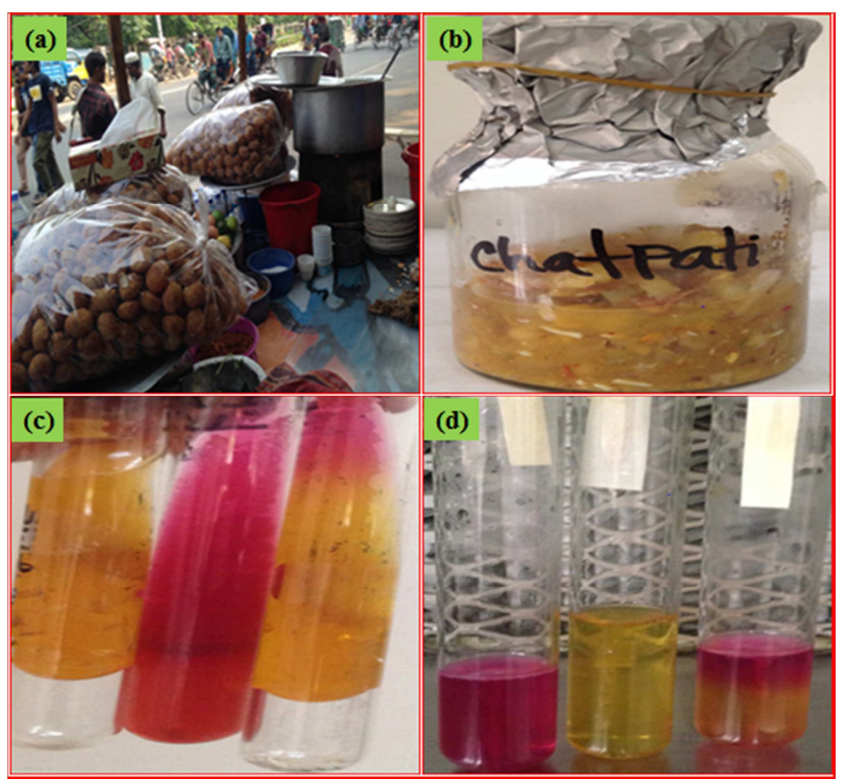

Figure 1. (a) Spot of CHT collection, (b) Collected CHT sample, (c) KIA Test and (d) MIU Test.

Table 2. Biochemical test results.

\begin{tabular}{|c|c|c|c|c|c|c|c|c|c|c|}
\hline \multirow{2}{*}{ Isolates ID } & \multicolumn{4}{|c|}{ KIA Test } & \multicolumn{3}{|c|}{ MIU Test } & \multirow{2}{*}{$\begin{array}{l}\text { Oxidase } \\
\text { Test }\end{array}$} & \multirow{2}{*}{$\begin{array}{l}\text { Catalase } \\
\text { Test }\end{array}$} & \multirow{2}{*}{ Identification } \\
\hline & Slant & Butt & $\mathrm{H}_{2} \mathrm{~S}$ & Gas & Motility & Indole & Urease & & & \\
\hline $1 / \mathrm{SB} / 1$ & A & A & - & + & - & - & + & - & + & Klebsiella spp. \\
\hline $1 / \mathrm{SB} / 2$ & A & A & - & + & + & + & - & - & + & E. coli \\
\hline 2/SW/1 & A & A & - & + & - & - & + & - & + & Klebsiella spp. \\
\hline $2 / \mathrm{SW} / 2$ & A & A & - & + & + & + & - & - & + & E. coli \\
\hline 3/REG/1 & A & A & - & + & + & + & - & - & + & E. coli \\
\hline 3/REG/2 & A & A & - & + & + & + & - & - & + & E. coli \\
\hline 4/RH/2 & A & A & - & + & + & - & - & - & + & Enterobacter spp. \\
\hline 5/SN/1 & $\mathrm{K}$ & A & + & + & + & - & + & - & + & Proteus mirabilis \\
\hline $5 / \mathrm{SN} / 2$ & $\mathrm{~K}$ & A & - & + & + & + & - & + & + & Aeromonas spp. \\
\hline 6/DMC/1 & $\mathrm{K}$ & A & + & + & + & - & + & - & + & Proteus mirabilis \\
\hline 6/DMC/2 & $\mathrm{K}$ & A & - & - & + & + & - & + & + & Vibrio spp. \\
\hline $7 / \mathrm{CH} / 2$ & A & A & - & + & + & - & - & - & + & Enterobacter spp. \\
\hline $7 / \mathrm{CH} / 3$ & $\mathrm{~K}$ & A & + & + & + & - & + & - & + & Proteus mirabilis \\
\hline
\end{tabular}

$\mathrm{K}=$ alkaline reaction (red color), $\mathrm{A}=$ acid reaction (yellow color), $+=$ positive reaction, - = negative reaction.

Although some pathogenic bacteria have been found in CHT samples inside Dhaka University campus, the load is relatively lower than the previous study conducted in one of the busiest areas, Motijheel, Dhaka city. We found average bacterial load of $4.68(\log \mathrm{CFU} / \mathrm{g})$ compared to $8.8(\log \mathrm{CFU} / \mathrm{g})$ reported by Tabashsum et al. 2013 [28]. Dhaka University campus is relatively less crowded than Motijheel of Dhaka city which might contribute to the lower bacterial load in the collected samples. Similar results were found by Tambekar et al. 2011 [29]. In that study, samples collected from crowded areas were more contaminated than the samples from non-crowded areas. The street vendors in Dhaka University campus sell CHT in a relatively hygienic condition. Moreover, for the preparation of CHT, vendors collect water from University campus which is safer than other parts of Dhaka city. The $\mathrm{pH}$ of the samples ranged from 4.5 to 5.5 . This acidic $\mathrm{pH}$ may be another 
underlying cause of lower bacterial load. Apart from this, the turn-over rate of this food item is very high and therefore there is fewer chance of selling stale food and also the food items were found to be kept in heating all the time. All of these factors might contribute to the relatively better bacteriological quality of CHT sold inside Dhaka University campus.

Street-foods are also very popular in other south-east asian countries like India. The findings from the present study have been compared with the previously published reports on the similar types of street-foods from different locations of India. From the comparison, we observe that Gram-negative bacteria such as E. coli, Klebsiella spp., Enterobacter spp., Vibrio spp. and Pseudomonas aeruginosa were also identified from Panipuri and Bhelpuri samples (Table 3). Similar ingredients and preparation methods for CHT, Panipuri and Bhelpuri along with the same geographical location of Bangladesh and India may be the underlying causes for the presence of similar Gramnegative bacteria. However, identification of some potentially harmful Gram-negative bacteria such as Salmonella spp. and Shigella spp. has been reported on those studies. Tabashsum et al. 2013 also identified Salmonella spp. in CHT samples collected from the Motijheel area of Dhaka city, Bangladesh [28]. However, we did not find such type of bacteria in our samples. Therefore, it can be concluded that the CHT sold inside Dhaka University campus is relatively safer than CHT sold in other part of Dhaka city as well as safer than Panipuri and Bhelpuri sold in different regions of India.

Table 3. Gram-negative bacteria identified in similar types of street-foods from different regions of India.

\begin{tabular}{lll}
\hline Sample Name & Study Location & Identified Bacteria \\
\hline Panipuri & Tamil Nadu, & $\begin{array}{l}\text { E. coli, Klebsiella spp., Enterobacter spp., Vibrio spp., Salmonella spp., Shigella spp., } \\
\text { Yersinia spp. }\end{array}$ \\
Panipuri & Baripada city, Orissa & $\begin{array}{l}\text { E. coli, Klebsiella spp., Enterobacter spp., Vibrio spp., Salmonella paratyphi B., } \\
\text { Shigella dysenteriae }\end{array}$ \\
$\begin{array}{l}\text { Panipuri } \\
\text { Panipuri, Bhelpuri }\end{array}$ & Amravati & $\begin{array}{l}\text { E. coli, Klebsiella spp., Pseudomonas aeruginosa } \\
\text { [31] }\end{array}$ \\
\hline
\end{tabular}

From the antibiogram profiling it was observed that all of the isolates were sensitive to ciprofloxacin and colistin. Most of the isolates were resistant to ampicillin and nitrofurantoin, five isolates were resistant to chloramphenicol. The MRI percentage of the isolates ranged between 16.66-66.6 (Table 4). This is somewhat similar to the results reported by Madhuchhanda Das et. al. 2012 [31]. Pseudomonas aeruginosa showed the highest MRI percentage of 66.67 which was followed by Proteus mirabilis (50). E. coli, Klebsiella spp. and Enterobacter spp. showed MRI percentage of 33.33. Aeromonas spp. and Vibrio spp. showed the lowest MRI percentage of 16.66 which reflects their susceptibility towards the applied antibiotics.

Table 4. Results of antibiogram profiling with MRI percentage of isolates.

\begin{tabular}{|c|c|c|c|}
\hline \multirow{2}{*}{ Isolates } & \multicolumn{2}{|l|}{ Antibiotics } & \multirow{2}{*}{ MRI\% } \\
\hline & Sensitive to & Resistant to & \\
\hline Klebsiella spp. & CIP-5 $\mu \mathrm{g}(22)$, CRO-30 $\mu \mathrm{g}(27), \mathrm{CT}-10 \mu \mathrm{g}(11), \mathrm{C}-30 \mu \mathrm{g}(24)$ & AMP-10 $\mu \mathrm{g}(8)$, F-300 $\mu \mathrm{g}(13)$ & 33.33 \\
\hline Enterobacter spp. & CIP-5 $\mu \mathrm{g}(33)$, CRO-30 $\mu \mathrm{g}(20), \mathrm{CT}-10 \mu \mathrm{g}(13), \mathrm{C}-30 \mu \mathrm{g}(21)$ & AMP-10 $\mu \mathrm{g}(10), \mathrm{F}-300 \mu \mathrm{g}(6)$ & 33.33 \\
\hline E. coli & CIP-5 $\mu \mathrm{g}(25)$, CRO-30 $\mu \mathrm{g}(25), \mathrm{CT}-10 \mu \mathrm{g}(11), \mathrm{C}-30 \mu \mathrm{g}(24)$ & AMP-10 $\mu \mathrm{g}(9)$, F-300 $\mu \mathrm{g}(14)$ & 33.33 \\
\hline $\begin{array}{l}\text { Pseudomonas } \\
\text { aeruginosa }\end{array}$ & CIP-5 $\mu \mathrm{g}(25)$, CT-10 $\mu \mathrm{g}(12)$ & $\begin{array}{l}\text { AMP-10 } \mu \mathrm{g}(8), \mathrm{F}-300 \mu \mathrm{g}(6), \mathrm{CRO}-30 \\
\mu \mathrm{g}(13), \mathrm{C}-30 \mu \mathrm{g}(6)\end{array}$ & 66.67 \\
\hline Proteus mirabilis & CIP-5 $\mu \mathrm{g}(25)$, CRO-30 $\mu \mathrm{g}(26)$, CT-10 $\mu \mathrm{g}(12), \mathrm{C}-30 \mu \mathrm{g}(25)$ & AMP-10 $\mu \mathrm{g}(12), \mathrm{F}-300 \mu \mathrm{g}(14)$ & 50.00 \\
\hline Vibrio spp. & CIP-5 $\mu \mathrm{g}(26)$, CRO-30 $\mu \mathrm{g}$ (28), CT-10 $\mu \mathrm{g}$ (12), C-30 $\mu \mathrm{g}$ (26), F-300 $\mu \mathrm{g}$ (17) & AMP-10 $\mu \mathrm{g}(8)$ & 16.67 \\
\hline Aeromonas spp. & CIP-5 $\mu \mathrm{g}(27)$, CRO-30 $\mu \mathrm{g}(25)$, CT-10 $\mu \mathrm{g}(12), \mathrm{C}-30 \mu \mathrm{g}(27), \mathrm{F}-300 \mu \mathrm{g}$ (19) & AMP-10 $\mu \mathrm{g}(10)$ & 16.67 \\
\hline
\end{tabular}

Values in parentheses represents the zone of sensitivity in millimeters (mm); AMP-10= Ampicillin $10 \mu \mathrm{g}, \mathrm{CT}-10=\mathrm{Colistin} 10 \mu \mathrm{g}$, CIP-5 $\mu \mathrm{g}=\mathrm{Ciprofloxacin} 5$ $\mu \mathrm{g}, \mathrm{CRO}-30 \mu \mathrm{g}=$ Ceftriaxone $30 \mu \mathrm{g}, \mathrm{F}-300 \mu \mathrm{g}=$ Nitrofurantoin $300 \mu \mathrm{g}$, C-30 $\mu \mathrm{g}=$ Chloramphenicol $30 \mu \mathrm{g}$; MRI = Multiple Antibiotic Resistance Index.

On February 27, 2017 WHO published the first ever list of antibiotic resistant bacteria termed as "priority pathogen" that included 12 families of bacteria posing greatest threat to human health. The list emphasized specially on multidrug resistant Gram-negative bacteria. The list is categorized as: critical, high and medium priority based on urgency to develop new antibiotics. Multidrug resistant bacteria posing a great threat in hospital patients are considered as priority-1 category (Critical Group) including Acinetobacter baumannii, Pseudomonas aeruginosa and various Enterobacteriaceae (Klebsiella, E. coli, Serratia and Proteus). The alarming issue is that these bacteria are now resistant to a large number of antibiotics such as to carbapenems and third generation cephalosporins. The priority-2 and priority-3 categories include drug resistant bacteria which lead to common diseases like gonorrhea and food borne diseases [32]. In this present study, we have also identified the aforementioned top priority bacteria in the CHT samples. Among the identified bacteria, Pseudomonas aeruginosa is a ubiquitous and versatile human opportunistic pathogen that requires minimum nutrients for growth [3334]. In recent years, several studies have been conducted in big cities of Bangladesh to get an insight of the antibiotic resistant nature of Pseudomonas aeruginosa. The findings from these studies are briefly summarized in Table 5. 
Table 5. Summary of researches carried out in Bangladesh in recent years on antibiotic resistant Pseudomonas aeruginosa.

\begin{tabular}{|c|c|c|c|c|}
\hline Study Location & Sample Type & Natt & f Resistance & References \\
\hline \multirow[b]{2}{*}{ Chittagong } & \multirow[b]{2}{*}{ Swab from burn wounds } & Type & Resistant to & \multirow[b]{2}{*}{35} \\
\hline & & $\begin{array}{l}\text { Pseudomonas. aeruginosa CU1 } \\
\text { Pseudomonas. aeruginosa CU2 }\end{array}$ & $\begin{array}{l}\text { All Applied Antibiotics } \\
\text { Amoxicillin, Ampicillin and Gentamicin }\end{array}$ & \\
\hline \multirow{8}{*}{ Noakhali, Chittagong } & \multirow{8}{*}{$\begin{array}{l}\text { Swab from mobile phone of } \\
\text { healthcare workers }\end{array}$} & & istant to & \multirow{8}{*}{36} \\
\hline & & Antibiotic & Percentage & \\
\hline & & Ceftazidime & 45.5 & \\
\hline & & Tetracycline & 45.5 & \\
\hline & & Cefotaxime & 36.4 & \\
\hline & & Ciprofloxacin & 36.4 & \\
\hline & & Imipenem & 36.4 & \\
\hline & & Gentamycin & 27.3 & \\
\hline \multirow{15}{*}{ Dhaka City } & \multirow{15}{*}{$\begin{array}{l}\text { Water from various ponds, } \\
\text { lakes and rivers }\end{array}$} & \multicolumn{2}{|c|}{ Resistant to } & \multirow{15}{*}{37} \\
\hline & & Antibiotic & Percentage & \\
\hline & & Ampicillin & 100 & \\
\hline & & Tetracycline & 93.7 & \\
\hline & & Gentamicin & 93.7 & \\
\hline & & \multicolumn{2}{|c|}{ Moderately resistant to } & \\
\hline & & Antibiotic & Percentage & \\
\hline & & Co-trimoxazole & 71.8 & \\
\hline & & \multicolumn{2}{|c|}{ Marginal resistant to } & \\
\hline & & Antibiotic & Percentage & \\
\hline & & Polymixin-B & 21.8 & \\
\hline & & Colistin & 12.5 & \\
\hline & & \multicolumn{2}{|c|}{ Sensitive to } & \\
\hline & & Antibiotic & Percentage & \\
\hline & & Ciprofloxacin & 100 & \\
\hline \multirow{8}{*}{$\begin{array}{l}\text { Dhaka Medical } \\
\text { College Hospital }\end{array}$} & \multirow{8}{*}{$\begin{array}{l}\text { Wound swab, urine, pus, } \\
\text { aural swab }\end{array}$} & \multicolumn{2}{|c|}{ Resistant to } & \multirow{8}{*}{38} \\
\hline & & Antibiotic & Percentage & \\
\hline & & Cefixime & 93.3 & \\
\hline & & Co-trimoxazole & 93.5 & \\
\hline & & Ceftazidime & 86.8 & \\
\hline & & Gentamycin & 77.3 & \\
\hline & & Ciprofloxacin & 75.5 & \\
\hline & & Imipenem & Least Resistance & \\
\hline
\end{tabular}

\section{Conclusion}

In this present study, significant bacterial loads have been found in different CHT samples. The results of the study were compared with the previously conducted study outside the Dhaka University campus. The comparison reveals that bacteriological quality of CHT, sold in Dhaka University campus, is relatively better than CHT sold outside the campus. Majority of the isolates showed resistance against the applied antibiotics. Ampicillin resistance was found in 92.307\% isolates. Resistance was also found against Nitrofurantoin, Chloramphenicol and Ceftriaxone. The presence of E. coli, Pseudomonas aeruginosa, Klebsiella spp., Vibrio spp., Enterobacter spp. etc. along with their multiple drug resistance characteristic may be severely detrimental to public health. Development of multiple antibiotic resistances among bacteria is a global public health concern today; hence, presence of such bacteria in street-food items as reported in this study is highly alarming. Therefore, it can be concluded that CHT sold in the streets of Dhaka University campus is not safe for health. Immediate public awareness should be raised so that contaminant free CHT is ensured for the consumers. Apart from this, several studies are required for visualizing the insight of the spreading of antibiotic resistance through food chains.

\section{References}

[1] Mead, G. (2004) Microbiological quality of poultry meat: a review. Revista Brasileira de Ciência Avícola. 6 (3): 135-142.

[2] Dawson, R., Canet, C. (1991) International activities in street foods. Food Control. 2 (3): 135-139.

[3] Ackah, M., Gyamfi, E., Anim, A., Osei, J., Hansen, J., Agyemang, O. (2011) Socio-economic profile, knowledge of hygiene and food safety practices among street-food vendors in some parts of Accra-Ghana. Int. J. Food Safety. 13: 191-197.

[4] Muzaffar, A. T., Huq, I., Mallik, B. A. (2009) Entrepreneurs of the streets: an analytical work on the street food vendors of Dhaka city. Int. J. Bus. Manage. 4 (2): 80-88.

[5] Rane, S. (2011) Street vended food in developing world: hazard analyses. Indian J. Microbiol. 51 (1): 100-106.

[6] Zain, M. M., Naing, N. N. (2002) Sociodemographic characteristics of food handlers and their knowledge, attitude and practice towards food sanitation: a preliminary report. Southeast Asian Trop. Med. Public Health. 33 (2): 410-417. 
[7] Bhowmik, S. (2012) Street vendors in the global urban economy. Taylor \& Francis.

[8] Barro, N., Bello, A. R., Savadogo, A., Ouattara, C. A. T., IIboudo, A., Traoré, A. S. (2006) Hygienic status assessment of dish washing waters, utensils, hands and pieces of money from street food processing sites in Ouagadougou (Burkina Faso). African J. Biotechnol. 5 (11): 1107-1112.

[9] Mensah, P., Yeboah-Manu, D., Owusu-Darko, K., Ablordey, A. (2002) Street foods in Accra, Ghana: how safe are they? Bul. W. H. O. 80 (7): 546-554.

[10] Al Mamun, M., Rahman, S. M. M., Turin, T. C. (2013) Microbiological quality of selected street food items vended by school-based street food vendors in Dhaka, Bangladesh. Int. J. Food Microbiol. 166 (3): 413-418.

[11] Biswas, S., Parvez, M., Shafiquzzaman, M., Nahar S., Rahman, M. (2010) Isolation and characterization of Escherichia coli in ready-to-eat foods vended in Islamic University, Kushtia. J. Bio-Sci. 18: 99-103.

[12] Tambekar, D. H., Jaiswal V. J., Dhanorkar, D. V., Gulhane, P. B., Dudhane, M. N. (2008) Identification of microbiological hazards and safety of ready-to-eat food vended in streets of Amravati City, Indian J. Appl. Bio-Sci. 7: 195-201.

[13] Food and Agriculture Organization (2012) The state of food insecurity in the world 2012. http://www.fao.org/docrep/016/i3027e/i3027e00.htm.

[14] Levy, S. B. (1992) The antimicrobial paradox. How miracle drugs are destroying the miracle. New York: Plenum Press.

[15] Mathur, S., Singh, R. (2005) Antibiotic resistance in food lactic acid bacteria - a review. Int. J. Food Microbiol. 105 (3): 281-295.

[16] World Health Organization (2014) Antimicrobial resistance: global report on surveillance.

[17] Chadwick, D. J., Goode, J. A. (2008) Antibiotic resistance: origins, evolution, selection and spread. John Wiley \& Sons. Vol. 207.

[18] Poole, K. (2002) Mechanisms of bacterial biocide and antibiotic resistance. J. Appl. Microbiol. 92 (s1): 55S-64S.

[19] Desjardins, R. M., Bradbury, N. C., Seyfried, P. L. (1988) Effects of metals from mine tailings on the microflora of a marsh treatment system. Aquatic Toxicology and Hazard Assessment: Vol. 10: ASTM International.

[20] American Public Health Association, American Water Works Association, Water Pollution Control Federation, Water Environment Federation. (1913). Standard methods for the examination of water and wastewater. American Public Health Association.

[21] Bergey, D. H., Boone, D. R., Castenholz, R. W., Garrity, G. M. (2001). Bergey's manual of systematic bacteriology. Vol. 1, Archaea and the deeply branching and phototrophic bacteria. Springer.

[22] Bauer, A., Kirby, W., Sherris, J. C., Turck, M. (1966) Antibiotic susceptibility testing by a standardized single disk method. Am. J. Clin. Pathol. 45 (4): 493-496.

[23] Mahapatra, S., Nishimura, R. A., Sorajja, P., Cha, S., McGoon, M. D. (2006) Relationship of pulmonary arterial capacitance and mortality in idiopathic pulmonary arterial hypertension. J. Am. Coll. Cardiol. 47 (4): 799-803.

[24] Microbiological guidelines for food (2014) http://www.cfs.gov.hk/english/food_leg/files/food_leg_Microb iological_Guidelines_for_Food_e.pdf.

[25] Bryan, F. L. (1988) Risks of practices, procedures and processes that lead to outbreaks of foodborne diseases. J. Food Prot. 51 (8): 663-673.

[26] Das, A., Nagananda, G., Bhattacharya, S., Bhardwaj, S. (2010) Microbiological quality of street-vended indian chaats sold in Bangalore. J. Biol. Sci. 10 (3): 255-260.

[27] Su, Y.-C., Liu, C. (2007) Vibrio parahaemolyticus: a concern of seafood safety. Food Microbiol. 24 (6): 549-558.

[28] Tabashsum, Z., Khalil, I., Nazimuddin, M., Mollah, A., Inatsu, Y., Bari, M. L. (2013) Prevalence of foodborne pathogens and spoilage microorganisms and their drug resistant status in different street foods of Dhaka city. Agric. Food Anal. Bacteriol. J. 3: 281-292.

[29] Tambekar, D., Kulkarni, R., Shirsat, S., Bhadange, D. (2011) Bacteriological quality of street vended food panipuri: A case study of Amravati City (MS) India. Biosci. Discovery. 2 (3): 350-354.

[30] Subhashini, R., Suganthi, R., Krithika, A., Poorani, S., Gopakumar, C., Alliddawi, I. M. I. (2014) Screening and sequencing of antibiotic resistant microorganisms from street food. Int. J. Pharm. Sci. Rev. Res. 24 (1): 224-229.

[31] Das, M., Rath, C. C., Mohapatra, U. (2012) Bacteriology of a most popular street food (Panipuri) and inhibitory effect of essential oils on bacterial growth. J. Food Sci. Technol. 49 (5): 564-571.

[32] http://www.who.int/mediacentre/news/releases/2017/bacteriaantibiotics-needed/en/.

[33] Franco, B. E., Martinez, M. A., Rodríguez, M. A. S., Wertheimer, A. I. (2009) The determinants of the antibiotic resistance process. Infect. Drug Resist. 2: 1-11.

[34] Altoparlak, U., Erol, S., Akcay, M. N., Celebi, F., Kadanali, A. (2004) The time-related changes of antimicrobial resistance patterns and predominant bacterial profiles of burn wounds and body flora of burned patients. Burns. 30 (7): 660-664.

[35] Nath, P. D., Chowdhury, R., Dhar, K., Dhar, T. Dutta, S. (2017) Isolation and identification of multi-drug resistant Pseudomonas aeruginosa from burn wound infection in Chittagong city, Bangladesh. IOSR J. Pharm. Biol. Sci. 12 (3): 43-47.

[36] Debnath, T., Bhowmik, S., Islam, T., Chowdhury, M. M. H. (2017) Presence of multidrug resistant bacteria on mobile phones of healthcare workers accelerates the spread of nosocomial infections and regarded as a threat to public health in Bangladesh. J. Microsc. Ultrastruct. (Article in press).

[37] Nasreen, M., Sarker, A., Malek, M. A., Ansaruzzaman, M., Rahman, M. (2015) Prevalence and resistance pattern of Pseudomonas aeruginosa isolated from surface water. Adv. Microbiol. 5 (1): 74-81.

[38] Rashid, A., Chowdhury, A., Rahman, S. H., Begum, S. A., Muazzam, N. (2007) Infections by Pseudomonas aeruginosa and antibiotic resistance pattern of the isolates from Dhaka Medical College Hospital. Bangladesh J. Med. Microbiol. 1 (2): 48-51. 